\title{
EDUCATION, EMPLOYABILITY AND LABOUR FORCE COMPETITIVENESS IN CROATIA
}

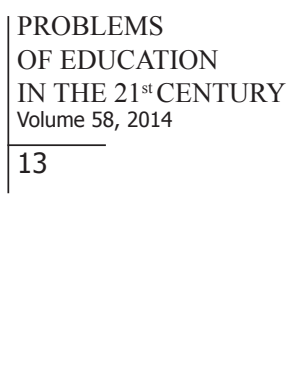

\author{
Predrag Bejaković \\ Institute of Public Finance, Zagreb, Croatia \\ E-mail: predrag@ijf.hr
}

\begin{abstract}
Employability and labour force competitiveness are important parts of an economy's overall competitiveness. The key role of knowledge as a structural part of the competence in stimulating economic growth has been widely recognised by economists and other scientists. In modern societies, the acceptance and development of knowledge, skills and ideas have a crucial role in the creation of wealth. The key determinant of a knowledge-based economy is human capital, or more precisely its knowledge, competence and ability. In many modern employment strategies there has been great emphasis on worker employability. The general idea of employability is not new, although only in recent times efforts have been made to define it clearly as policy has shifted emphatically towards supply side issues. Employability can be defined as the extent to which employees have skills, which the market and employers regard as attractive and is of increasing importance for the economic sector. The aim of this research is to provide an overview of the relationship between education, employability and labour force competitiveness in Croatia.

Key words: competitiveness, Croatia, educational system, employability, knowledge-based society, labour force.
\end{abstract}

\section{Introduction}

The economic theory in general, and particularly labour economics, has long emphasized the importance of research and development, employee expertise and knowledge, and social capital as vital and essential prerequisites for competitiveness and economic growth (Aghion and Howitt, 1998). The key role of competence and knowledge in stimulating economic growth has been widely recognised by economists and other scientists. OECD (2001) underlines how changing economic and social conditions have given knowledge and skills - human capital an increasing central role in the economic success of nations and individuals. However, their respective meanings vary in the world's developed countries (technology leaders) and less developed countries. Barro and Sala-i-Martín (1995) have shown that the level of education (measured by years of schooling), as well as public sector allocations for education, exhibit a high correlation to growth in real per capita income. Benhabib and Spiegel (1994) have established that the degree of education influences economic growth primarily through technological innovations, as well as through the speed of the assumption and spread of new technologies. To be sure, numerous studies (Haddad et al, 1999, Landes, 1999, Acemoglu and Robinson, 2012) have shown that the impact of education and research on development is scant at low developmental levels. Then, a certain level of development is achieved; the average number of years of education completed by the employed and the investments in research and development are positively linked to economic development (Meier and Rauch, 2000).

Guisan, Aguayo and Exposito (2001) confirmed that educational attainment is positively correlated with industrial development and underlined that the impact of education is also seen in other auxiliary phenomena like the preservation and maintaining of liberty, peace, cooperation, trust and other institutional benefits that contribute to socio-economic development of the 
Predrag Bejaković. Education, Employability and Labour Force Competitiveness in Croatia

PROBLEMS

OF EDUCATION

IN THE $21^{\text {st }}$ CENTURY

Volume 58,2014

14

creation of human capital, but also the invigoration of socially beneficial capital as well as the minimization of dysfunctional forms of social capital. Education doubtlessly carries ancillary non-market effects (for example, easier access to information, greater care for personal health, more active participation in social life which encourages responsible democratic civic behaviour, election of democratic authorities and actualization of the rule of law). Education should enhance employability and labour force competitiveness. This should make it easier to find a job, lessen long-term unemployment, contribute to the lowering of expenditures for social welfare purposes and redirect them to the incentive of economic growth and development. Improved employability and labour force competitiveness should contribute to empowering poor people, thereby demonstrating how they can significantly influence their destiny through qualifications, training and education and improve their unfavourable conditions.

At the first glance it seems that it is senseless to discuss employability and competitiveness at the national level because of the complexity of various impacts and determinants. According to the new theories (or models) of endogenous growth, it looks like there are reasons for analysing the mentioned factors. Unlike the traditional neoclassical theory of economic development and growth, this theory claims that the improvement of human capital produces positive effects, so called externalities. It is the case of knowledge and skills that are spread through the whole economy and society (Straubhaar, 2000). In that way, countries with higher level of human capital and better labour force competitiveness also develop faster and have higher rates of economic growth. As a whole, numerous studies (World Economic Forum, 1997; Porter, 1990) confirm that economic competitiveness and GDP growth are influenced positively by an increase in the share of persons over 25 years of age who have completed secondary, college and higher education and the index of the rule of law (quality of governmental administration, political corruption, probability that the government will not respect contractual agreements, risk of government expropriation and general respect for the rule of law). Better education of the general populace and the labour force and lower public spending improve a country's attractiveness to foreign investors (Sachs, Zinnes and Eilat, 1999), which facilitates the acceptance and development of modern technological and organizational solutions, paves the way for the rule of law and limits the extent of the informal (unofficial) economy (Semjen and Toth, 2002), increases demands for education and in turn spurs the competitiveness of the economy.

Education has been recognised as a cornerstone of economic and social development. More recently, however, it has become even more important to the development process as accelerated technological change and new organizations of production transform the world economy. A serious problem in Croatian society is high unemployment. One of the main reasons for the high unemployment incidence in Croatia is low educational attainment and/or widespread skill mismatches, because many unemployed are without adequate education or with obsolete knowledge and competences. The goal of researchers in the paper is to examine current situation and to provide an insight into the role of education in improving employability and the linked concept of individual competitiveness in the Croatian context. The analysis has been done with the purpose to propose measures for improvement because of the detailed data on the major areas of educational policy and practices are available to produce a new analysis of these challenges and to recommend coherent, practical policies for the future. This study is necessary because till now in Croatian context there were almost no similar analysis.

\section{Link between Employability and Competitiveness}

Employment plays a fundamental role in every society. People are often defined, and define themselves, through what they do for a living. Sociological and economic studies emphasise that not only is employment a primary source of status in every country, but it is also significant in providing purpose, income, social support, structure to life and a means of participating in society (Jahoda, 1982). Employment can be considered the glue that holds together 
the whole community. Market incentives for increased investment in education, training and attaining skills can have a role in reducing increased inequalities in employment possibilities and salaries, which are linked with the perils of exposure to poverty. If people had been employed previously, this resulted in a lower probability of unemployment. Therefore, all countries try to achieve that people work and earn a living. In order to obtain a job and to keep it, competitiveness and individual employability are crucial factors. Simultaneously, labour force competitiveness and employability are preconditions for the realisation of the total economic and social development.

In traditional industries, most jobs require employees to learn how to perform routine functions, which, for the most part, remain constant over time. A key component in a knowledgebased economy is human capital, or, more accurately, its competencies. In the knowledge-based economy, rapid changes force workers to constantly acquire new skills and to update their skills throughout their lifetimes. The capacity of producing, dispersing and using the knowledge and information becomes even more important and often is considered as the most important factor that determines the economic growth and quality of life.

In Dearing Report (1997) the term employability skills is commonly used to cover a group of key basic and transferable skills. The main areas that are highlighted as being beneficial to employers and, therefore, to current and future workers include: problem solving skills, communication skills, analytical skills, data analysis, critical appraisal, time management, and team working. According to the ILO (2002) employability is defined more broadly. It is a key outcome of high quality education, as well as a range of other policies. It encompasses the skills, knowledge and competencies that enhance a worker's ability to secure and retain a job, progress at work and cope with change, secure another job if she/he so wishes or has been laid off, and enter more easily into the labour market at different periods of the life cycle. Individuals are most employable when they have broad-based education and training, basic and portable high-level skills, including teamwork, problem solving, information and communications technology (ICT) and communication and language skills, learning to learn skills, and competencies to protect themselves and their colleagues against occupational hazards and diseases. This combination of skills enables them to adapt to changes in the world of work. Employability also covers multiple skills that are essential to secure and retain decent work. Employability of the labour force is particularly important during a crisis, due to circumstances of limited employment possibilities.

The importance of employability and labour force competitiveness has become crucial in the last 25 years due to enlarged economic globalisation. Employers are faced with vast requirements as a result of increased market competitions, so they demand from their employees a rapid and successful adaptation to the changes in the production, services and business procedures. That is the reason why employers more and more employ in non-standard forms like work on fixed contract, part-time work and others. Therefore, the labour market polarizes individuals employed for an indefinite period and persons who work on fixed-term, shorter working hours and/or on seasonal jobs. Investments in improvement of employability have mostly been directed to the first group of employees because the improvement of applied knowledge, skills and competitiveness of a particular worker is not beneficially only from the viewpoint of the company in which he or she currently works, but also his or her value grows in the external labour market.

Most of the modern literature (OECD, 2005, OECD, 2009) is concerned with employability and competitiveness approaches regarding transferable knowledge, skills and competences. Yet the effects of employability are not confined to individuals. Employers are therefore faced with conflicting risks. When they enhance their workers' employability, they are incurring costs in expectation but not certainty of boosting their own firms' potential productivity and profits (Atkinson, 1984). But investments in workers' transferable skills imply that other "poaching" firms will reap part of the benefits (Acemoglu and Pischke, 1999).

On the other side, a low level of employability is strongly correlated to long-term unem- 
Predrag Bejaković. Education, Employability and Labour Force Competitiveness in Croatia

PROBLEMS

OF EDUCATION

IN THE $21^{\text {st }}$ CENTURY

Volume 58,2014

ployment, poverty and social exclusion. The problems faced by many of the long term jobless are often multi-dimensional and frequently include low levels of education, lack of working experience and motivation. Individuals who are unemployed for long durations forget their knowledge, ability and skills or they become obsolete. Such persons often lose self-esteem and believe that they can't find a job. The mentioned factors result in such people being uncompetitive in the labour market. Employer recruitment practices tend to discriminate against long term unemployed people because long term unemployment is often used by employers as an indicator of lack of motivation and other undesirable personal traits.

\section{Links between Education, Employability and Competitiveness: Are There Limits?}

Numerous empirical studies (Griffith, 2000; Riddell, 2004; OECD, 2009) have been dedicated to the consideration of the return on investment in education and in research and development at the level of individual companies or individual economic sectors. The rates of return clearly show that education is important to overall economic growth, which provides one of the most crucial explanations for State support and financing of this activity. Decisions by individuals to undertake education and by companies to finance the education of their employees are based on actual or expected private returns on investment. According to OECD (2009) tertiary type, A educational attainment significantly benefits individuals in terms of earnings and employment.

A number of authors, like Griliches (1984), Griffith (2000) and Hall (2002), believe that this return is considerably lower than the total social return, therefore (without State action) leading to insufficient investment in education. In the interest of securing an optimal return on investment in education, research in developmental policies must discern between private return on investment from investment with social benefits. Thus, attempts must be made to compare the private and social returns on investment in education. It is relatively difficult to isolate only the significance of education in growth in production, competitiveness and economic growth, although normally this is done by assessing the elasticity of production with regard to available capital goods. Despite many difficulties involved in making measurements, there is a considerable number of well-grounded studies (particularly OECD, 2006; OECD, 2009) which unambiguously show that social rates of return on investment in education are considerably higher than private rates. Hall (1996) estimates that private rates of return from these investments are most often 10-15\% (although it can grow to as much as 30\% in individual activities and firms), while the social rates are greater by a factor of at least one fourth to one third. Trostel, Walker and Woolley (2002), according to estimates of the economic return to schooling for 28 countries, suggest that a worldwide average rate of return to schooling is of just under $5 \%$ for men, and a little under $6 \%$ for women. Also, there is a great deal of variation in the return to education across countries. The bulk of evidence shows that there are usually significant private returns to those who participate in higher education (the average private rate of return from higher education is close to $9 \%$ across ten OECD countries - Commission of the European Communities Brussels, 2006), and that these are not entirely offset by progressive tax systems. This can have a reverse redistribution effect. This regressive effect is particularly acute where school systems exacerbate the effects of socio-economic background on educational attainment.

One of the most important reasons why the social returns on investment in education, research, and development are considerably higher than private returns is due to knowledge spill-over from one firm to another. When something is discovered or invented, other producers or service providers can easily utilize it. The general belief is that knowledge and innovations are a type of public good whose consumption is not limited solely to one consumer, and it is almost impossible or very difficult to exclude an individual and/or firm from consumption of such a good (Cullis and Jones, 1998). In fostering labour force competitiveness, the State's role cannot simply be limited to financing education, rather it has to make information on the 
possibilities, benefits and need for education and on scientific achievements accessible, so that (at least partially) it can rectify the asymmetry of information ${ }^{1}$, the peril of moral hazards ${ }^{2}$ and adverse selection $^{3}$, all of which can have a negative impact on labour force competitiveness and the economy as a whole. Barro and Lee (2001) concluded that school outcomes, i.e. comparable test scores, repetition rates and dropout rates are highly influenced by some other factors, particularly family characteristics like the income and education of parents, but also school factors like size of the class, average teachers' salary and the length of the school term.

Most researchers agree that human capital ${ }^{4}$ is an essential component of competitiveness and economic development (return on investment in education is greater than that of any other investment - Benhabib and Spiegel, 1994; Barro, 1998.), but this is no guarantee of development because countries with the finest human capital do not necessarily achieve the best developmental results. The links between education ${ }^{5}$, competitiveness and economic development are not entirely clear, and what exactly constitutes a well- and successfully-educated labour force is even less so. Under conditions of rapid technological development and commerce based increasingly more on conceptual rather than on material production, academic diplomas and degrees are no longer a guarantee of economic success to either individuals or society as a whole.

It is particularly true in transition countries that the existing educational level of the employed and the population as a whole is no guarantee of competitive ability and economic growth. There are a number of reasons why, and here an attempt shall be made to consider several of them. The labour force can easily be insufficiently or inappropriately educated ${ }^{6}$, i.e. the (formally educated ${ }^{7}$ ) employed do not have the know-how necessary for successful market competition. Here expertise is not sufficient: employees today have to be capable of creating, analysing and transforming information, communicating effectively, and organizing and coordinating business activities. Developed communication skills, computer knowledge, and the ability and willingness to engage in further education and training are all sought-after qualities (Miyamoto, 2003).

Educational programmes in the transition countries of Central and Eastern Europe (particularly those based on the Austro-German model) are more oriented towards the rote memorization of course materials than on independent analytical/critical thinking and deduction and the innovative approach, which is certainly a hindering factor in other approaches to education and future work. Today the emphasis is placed on analytical abilities: seeking and

1 Some participants have better information than others, while some may have no access to information at all.

2 Behaviour by individuals (or companies) knowing, that others will bear the consequences of their illconsidered or flawed decisions.

3 A situation that emerges when individuals (or companies) purchase certain forms of insurance from which they will most likely derive benefits.

4 Human capital is a total of labour force knowledge, skills and experiences. It is critical resource of values for every firm if it is managed properly.

5 Education encompasses institutions $\_$processes, content and results of organised and/or the accidental learning in development of various cognitive skills as well as achieving different knowledge, abilities and habits. Most often education relates to the procedure of acquiring of knowledge and ability. Education is usually divided on formally - in schools, and informal - outside of the school.

6 According to numerous OECD and World Bank sources, in many South American countries there is a great number and high share of lawyers and literature and philosophy professors among their educated population, while in the Scandinavian countries there are many persons studying electronics, IT, management, etc. (Blomström and Meller, 1991). This is not to negate the importance of the first group of the highly-educated, but the second group is nonetheless vital to economic development. Although there are no comprehensive and uniform solutions that suit all needs, the structure of pupils and students should correspond as much as possible to the existing, and especially future, desired structure of the national economy.

7 The concept of human capital is broader than just the formal education of a population and its employees, because it should encompass all knowledge and skills acquired informally and, under the broadest definition, investments in health. The level of human capital need not be the same as the average level of formal education. 
Predrag Bejaković. Education, Employability and Labour Force Competitiveness in Croatia

PROBLEMS

OF EDUCATION

IN THE $21^{\text {st }}$ CENTURY

Volume 58, 2014

18

selecting information, clarifying problems, formulating assumptions, confirming and assessing evidence and finding solutions. Globalization has emphasized the importance of knowledge and the aforementioned qualities in employees, which become crucial features of the creation (or not) of competitive abilities in economic and free market competition. Furthermore, according to Sopek (2011) educational system is inefficient regarding the used financial resources and achieved results.

Porter (1990: 628) clearly recalls that education and training are the most important individual lever of the State at all levels of governance for the long-term improvement of the economy and the welfare of its citizens. The biggest challenge for these countries is not just to get the hardware, but to have the skills required to use the technology. Educational systems can no longer emphasise task-specific skills but must focus instead on developing the learners' decision-making, problem solving skills and teaching them how to learn on their own and with others. The importance of tertiary education is especially great, as it directly influences the productivity and competitiveness of a national economy and the improvement of general living standards (World Bank, 2002). In short, the educational structure of the population and employees in line with economic needs constitute an essential component of competitiveness and economic development.

\section{The Situation in Croatia}

According to OECD (2003), the considerable problems faced by the educational system in Croatia are: lack of emphasis on developing analytical and problem-solving abilities, very weak links between education and the professional world, and the non-development of lifelong learning. Although numerous education strategies have been proposed, they have neither been put into operation nor fully implemented, nor were any major reforms implemented at any level.

In Croatia, the current organization of the curriculum around subjects and teacher-dominated learning methods, with the focus on factual knowledge and passive learning, is not conducive to the development of the high-level technical, technological, and social competencies needed in a competitive economy. There are too many compulsory subjects and not enough optional subjects. There is a serious lack of flexibility and a low level of local capability for curriculum development.

A serious problem of elementary and secondary education is insufficient differentiation. The curricula for higher elementary grades are designed to continue on into secondary school (gymnasium) and not for continuation of schooling in vocational or trade schools (even though only one fourth of all elementary school pupils go on to study in the gymnasiums). Consequently, many primary school pupils suddenly find the primary school programme for the 7 th and 8th grades too difficult, and the existing opportunities for internal differentiation are not sufficient. Accordingly, students who are very capable and motivated find subject teaching too easy, while those who are less competent and less motivated find it too difficult. Vocational education forces subject-specific specialization too early, while the curriculum is too narrowly focused on subject-specific skills, competencies, and attitudes. Further, links with the economic and social environment are generally very weak. Due to technological developments and structural changes in the Croatian economy there is no longer a need for most of the existing specializations.

Croatia's tertiary system is so rigidly structured that institutions, faculties and students are unable to seize opportunities or adapt to change. One can say with relative assurance that the highly educated in Croatia have largely completed studies at university departments and academies that do not directly cater to the needs of a modern economy, and they often do not possess the vital and required knowledge and skill-sets for sought-after occupations. The number of those enrolled in tertiary education increased significantly but the average duration of college/ university study is very long. The number of students who go on to earn degrees in relation to the number of students enrolled in the first year is less than $40 \%$, while a large number of stu- 
dents discontinue their studies. Furthermore, there is a relatively low proportion of students majoring in the natural and technical sciences. There are serious problems with the knowledge and skills of graduates in social sciences. There is a severe shortage of macroeconomists, financial analysts, organizers and commodities- and securities-exchange operators, educated managers and entrepreneurs, international commodity and financial market experts, public administration experts, and lawyers specializing in labour and welfare law, the tax system, international law, etc. The reasons for these problems probably are caused by insufficient (or weak) links between the demand of the labour market and educational output. Finally, the most dynamic sector of education systems in the world, adult and lifelong education is seriously neglected in Croatia. It is underdeveloped, as far as the coverage of attendees, the number of specialized institutions and specialized staff are concerned, and it is insufficiently regulated by law. In Croatia only $2.5 \%$ of persons participate in one of the adult learning programmes, while according to the Eurostat (2009) the EU average for the total population is $35.7 \%$. No (serious) campaign has been launched yet to motivate and explain the concept and the need for life-long learning among the population due to relatively weak information and developmental infrastructure. The required infrastructure is undersized and some elements of the infrastructure simply do not exist or are yet to be built.

Therefore it is relatively certain that the Croatian labour force does not have the knowledge and skills required for a modern competitive economy. That is because the employees did not finish adequate schools, faculties and academies and/or they are insufficiently qualified or perhaps inappropriately qualified for the needs of the market economy. Based on different surveys and studies (OECD, 2003; Skjolstrup, 2008) it could be concluded that the educational system in Croatia is characterised by a lack of emphasis on developing analytical and problemsolving abilities, very weak links between education and the professional world, and the nondevelopment of lifelong learning. Although numerous education strategies have been proposed, they have not been put into operation and/or not fully implemented, nor were any major reforms implemented at any level. There is a need to systematically continue with the designing and development of educational programmes on which necessary experts would be taught, trained and educated. Efforts must be invested in educational and job-training programs, systematic coordination of education so that it complies with the needs of the market and encouragement of lifelong education. Investment in human capital is certainly desirable, but it probably will not produce results over the short term. An educated labour force is not, in and of itself, a sufficient developmental resource if it is not utilized to apply new technologies. In order to achieve this, technical know-how and management skills are needed throughout society. To achieve this technical expertise and adequate organisational and managerial capabilities the entire society must be incorporated. Equally important is the respect of employers' attitudes regarding skills, knowledge and characteristics of employees as well as improvement in the institutional environment and social capital.

\section{Employer Perceptions Regarding Employees' Expertise, Knowledge and Characteristics}

Croatian employers often complain (Poloski and Frajlic, 2004.; Moj posao, 2005.; Bejaković, Bratić, Sopek, Štefica, 2009.) about the educational system, particularly regarding vocational training, claiming that it does not follow economic trends and that many young people still acquire obsolete skills, knowledge and expertise. Technical skills of young persons are insufficient, while underdeveloped are key competences like informatics, literacy, communicational and numerical skills, teamwork, problem-solving abilities and independent initiative (Skjolstrup, 2008). Entrepreneurs thus underline a vast need for modernising curriculum of education, skills and qualification as well as a need for enhancement of labour force employability and competitiveness. 
Predrag Bejaković. Education, Employability and Labour Force Competitiveness in Croatia

PROBLEMS

OF EDUCATION

IN THE $21^{\text {st }}$ CENTURY

Volume 58,2014

Poloski and Frajlic (2004) used various methods to get an insight into needs and behaviour of Croatian employers. They also wanted to find out if current employees satisfy employers' requirements. The directors of HR departments have to define labour force competitiveness and employability. In their answers they stressed the need of knowledge and education, ability, devotion to work and taking over responsibilities. Based on the proposed list of skills and knowledge, Croatian employers mentioned morality, loyalty, literacy and basic knowledge as the second most important characteristics, while less important skills are related to knowledge of foreign languages, analytical skills and capabilities, information literacy and ability for teamwork.

A similar picture on educational needs has been obtained by the survey realised by Web portal Moj posao (2005). From the mentioned results, it can be concluded that $69 \%$ of Croatian employers believe that their employees should develop communicational and presentational skills. More than a half (56\%) of employers think that employees should enhance their leadership skills, while $53 \%$ mentioned skills of selling methods and sales techniques. Almost a half underline the importance of teamwork and management skills, while the share of those that value the knowledge of foreign languages, advanced informatics courses, management of human resource and knowledge on personal efficiency is just a little bit lower. Moj posao carried also a survey on employees' knowledge and training achievements. More than a half of interviewedemployers have been quite satisfied with formal education and training of their employees in technical and engineering occupations, economic and financial sector and the telecommunication field. On the other side, only one third have been satisfied with the qualifications of their employees in the legal profession. More than a third have been quite dissatisfied with formal education of employees on administrative activities, commercial mediation and economy.

In the analysis of the educational needs in small and medium enterprises with particular stress on entrepreneurial skills (Bejaković, Bratić, Sopek, Štefica, 2009), interviewed employers underlined informatics knowledge and skills as the most important for further enhancement, followed by communication skills and communication with the environment. At the end of the list of required characteristics are business analysis and controlling and strategic management as the least necessary skills for further improvement. For those who are not business leaders, the most important characteristics were orientation towards results, persistence and efficiency in work (expressed by $90.9 \%$ interviewed persons from 858 small and medium enterprises), loyalty and readiness to stay in enterprises even during business difficulties $(87.7 \%)$, readiness to introduce technical and technological innovations and improvements in the business $(86.9 \%)$ and readiness and openness for increasing and/or changing current activity of enterprise $(86.0 \%)$. The least desired characteristics were readiness and openness for increasing and/or changing current activity of enterprise $(67.0 \%)$ and readiness to take initiatives for the discovering and proposing of new solutions (75.6\%).

Although a significant number of employers were quite satisfied with knowledge and expertise of their employees, a noteworthy part was not satisfied. It looks like the education system produces knowledge and skills that are sought after by Croatian employers, because they believe that morality, loyalty, basic knowledge and literacy are at a respectably high level. The surveys show insufficient links between existing and required technical skills of employees, which confirms that the educational system - including lifelong learning - should be better adjusted to the labour market needs. Skills which Croatian employers consider important for highly educated and qualified workers are actually skills on which the educational system should be directed. It is necessary to emphasise that managers strongly appreciate good personal characteristics, openness towards others and communication capacity. Thus, along with better adjustments of educational programmes according to the labour market needs, it is also necessary to systematically work on their modernisation and preparation of participants to lifelong learning and development of skills. 


\section{Instead of Conclusion}

The important aspect of national economic competitiveness is the skill level and knowledge of the labour force. The acquisition of knowledge and skill is increasingly seen as both the main challenge and the central opportunity for achieving a successful return to the labour market and employment, and it is the most important determinant of social and economic prosperity of a country and its population. Education has a key role in acquiring knowledge, expertise and skills needed for successful participation in society and economy. Education also contributes to broadening of science and knowledge culture. Through the diffusion of new technologies and globalisation, industrial economies are being transformed into knowledge-economies.

The Croatian labour force does not have the knowledge and skills required for a modern competitive economy, and the education and training systems have not yet taken adequate steps to remedy this situation. Possible accession to the EU puts further onus on Croatia to concentrate on its education system. The Croatian work-force should move towards knowledge-based industries and jobs and innovation-driven economic growth, and workers should be able to change jobs quickly, manage themselves and others, and engage in continuous learning. Students and employees should learn to work together by developing a team spirit and appropriate social behaviour while at the same time allowing their individual preferences and talents to develop.

Croatia's education system, is slowly making the transition from a system that favoured rote-learning, discipline, and lecturing to a system that fits the needs of a democracy with a globally integrated free-market that needs problem-solving skills, creativity, communication skills, and flexibility. In spite of relatively large outlays that have been allocated for education, there is a weak link between the educational sector and labour market needs regarding the number of individuals that finish a particular educational programme, especially in respect to knowledge and competence acquired during education. Curricula and syllabi at all levels should be reformulated to bring them into closer correspondence with economic needs. Problem-solving abilities should be improved, teamwork should be encouraged, and learning skills should be enhanced. It is important to increase the ability to learn, develop students' capability to manage themselves and others, build communication and technical/ICT skills, and reduce the emphasis on rote-learning. Curricular reform should be accompanied by new textbooks, teacher guides and learning materials, changes in teaching methods, and new measures of learning outcomes.

Based on different surveys and studies by the World Bank (especially Berryman and Drabek, 2002), OECD (2001, 2003), comparisons with other European countries' education systems (Lowther, 2004) and current inefficiency (Sopek, 2011), we would like to propose the following recommendations:

- The education system should be changed from supply to demand-driven, i.e. the system should provide learning alternatives that students (of all ages) can choose from, with increasing responsibility for the students as they get older.

- The educational system must be made more flexible, so as to become a navigable system, thus avoiding dead-ends and lowering the early drop-out rate, increasing the internal differentiation of students, reinforcing informal methods of acquiring knowledge and skills, and improving knowledge of foreign languages. The systematic analysis, disburdening and modernization of educational curricula and programs are essential. As a necessary precondition there is a need to better collect data on the number of children and youth that do not finish primary, secondary and tertiary education. Croatian Bureau of Statistics does not collect systematically mentioned information and there is no official data about proportions of drop-outs from education. This data is necessary because of the structure analysis of youth which have not finished the education as well as the basic causes of dropping-out from schools.

- It is important to make the shift from teacher-focused teaching to teaching methods that give students responsibility for learning, reward initiative and executive thinking, 
PROBLEMS

OF EDUCATION

IN THE $21^{\text {st }}$ CENTURY

Volume 58,2014

22

focus on alternative ways to analyze facts and ideas and solve problems in a meaningful context.

- Management of the education system should be decentralized, i.e. budgeting, personnel, and curricula, should be within the authorised of the schools and local governments and universities instead of the Ministry. At the same time, schools and local governments must build the capacity to manage their schools effectively. Schools and universities should be responsible and accountable for their results and their performance should be measured by the success in the implementation of reforms. Increasing expenditures for education without an adequate rise in the accountability of those institutions will not provide expected results. Thus, the Government (Ministry) should set standards and hold schools accountable for learning outcomes, e.g. reading comprehension, information and communication technology skills, and give the schools and universities freedom to use their own methods to produce them.

- Government has the responsibility to put in place an enabling framework to encourage tertiary education institutions to be more innovative and responsive. Government should facilitate private provision where possible, restricting its controls to the area of consumer protection. These include quality assurance through mechanisms such as accreditation and impartial information about public and private institutions relevant to consumer choice. Furthermore, there is a need to insure quality through mechanisms of issue approvals and unbiased information about public and private institutions important for the user's possibilities for choice. Constant systematic evaluations of education system outcomes and comparisons are also important.

- It will be necessary to raise the enrolment quotas for specific majors in the natural and technical sciences, and increase the efficiency of studies, so that the largest possible number of the enrolled students completes their studies. As a necessary precondition there is a need to collect and analyse data on duration of education on particular university and college programmes. Croatia officially does not collect data on particular tertiary programmes, which is one of the basic preconditions for measuring the success of current reform of tertiary education. The mentioned reform, whose goal is education harmonisation in European area, is still faced with many unknown factors about possibilities for financing of its tangible and personnel requirements.

- Higher tuition fees could contribute to shorter average periods of study, and to greater fairness, because in this manner taxpayers, among whom there are those with lower incomes, would not bear the costs of educating persons whose future earnings will be higher than average. Also it is necessary to develop and support the system of awarding a scholarship for pupils and students. Possibilities of obtaining education are largely connected with financial possibilities. Thus, it is very important to combine criteria of the excellence and merits with criteria of social situation.

- It is particularly important to stimulate life-long learning, education and training as it is currently quite neglected and because of a very low rate of adult's participating in it, this is one of the key obstacles for the development of a flexible and adjustable labour market. In learning, education and training of employed and unemployed orientation should not only be towards IT literacy, but also on development of communication skills, stimulation of own and others' motivation, problem solving, improvement of participation in team work, acceptance of changes and other.

- In conjunction with radical reforms of curriculum, materials, and pedagogy, Croatia will need to vigorously train existing and new teachers including imparting new teaching methods, use of teaching materials, and testing methodology. Teachers should be required to receive life-long training on teaching skills and methods, use of information and communication technology, and subject matter.

- The government educational subsidy system should also be revised in order not only to foster excellence but also to help financially vulnerable groups in the education proc- 
ess. Therefore, scholarships and rewards should be directed to students with excellent academic achievements and to those from households with lower income level.

Although the autonomy of educational institutions, especially universities, must be upheld, it is also necessary to enhance their capabilities in management, accountability, reporting with reference to utilized funds, and improve their strategic planning capacity. Systematic measurement of the quality (assessment and monitoring) of educational and scientific research programs must be insisted upon. All interested parties (Government, interested ministries, regional and local bodies and social partners) should be involved in deliberations on these matters so that a social consensus can be achieved. This is not a simple task, nor even a guarantee of success, but, the absence of public involvement and decision-making behind closed doors is guaranteed to fail. The ongoing education of all participants in the reform of higher education and science, from decision-makers to the public, is absolutely essential to engendering an understanding of the significance of undertaken reforms.

Developing human capital is necessary, but not sufficient to secure labour force competitiveness. Generating economic competitiveness requires qualified and capable citizens and employees, but this must be accompanied by the appropriate economic policies - primarily the development of strong and independent institutions, improvement of public administration, curtailment of corruption and the informal economy, and improvement of the free enterprise environment. This is no simple task that can be accomplished quickly, but rather a clear developmental guideline in which citizens will see improvement in these sectors and can, in a relatively short period, produce valuable results.

Education is essential for the effectual creation, dissemination and application of knowledge and for the development of technical and expert/professional capacity. The ability of a society to produce, select, adapt, commercialize and utilize existing knowledge are decisive in the creation of sustainable and lasting economic growth and improvement of living standards, public health, and the reduction of poverty and inequality. Although there is no simple nor uniform formula for improving the education, qualifications and competitiveness of the labour force, which can be copied or automatically transferred from other countries or places, it is nonetheless clear that a general prerequisite is an unwavering vision of long-term development of all-encompassing, diverse, mutually linked and well-articulated educational, employment and professional advancement systems. The ability to formulate, synthesize, analyze and deliberate can be developed in a broad range of educational programmes and through various instructional approaches.

Advancement of the educational level of the population is an indispensable condition for competitiveness, but a complicated question arises here: How can the personal and social benefits of education be assessed? Education - especially higher education- is largely a kind of credence good. This means that its value is often difficult to quantify, even after it is consumed (the acquired knowledge is utilized). The basic problem is the impossibility of assessing the value of individual schools or universities by future pupils and students, which could reflect unfavourably on good educational institutions. In reality, students normally choose a school and university only once or twice in their lives (in cases of change), even as the educational experiences of former participants differ from each other greatly, as do their recommendations for future students. In a small country like Croatia, it is particularly difficult to create the necessary competition in providing educational services, and signal the quality of individual schools, colleges and universities. This therefore requires consistent and objective monitoring, assessment and publication of educational results of individual schools and universities, which in turn should be the most important determinant of future financing. These signals should encourage competition among educational institutions in attracting the best and most perspective pupils and students.

The formal improvement of the educational structure of the employed and the general populace will not be enough, because raising competitiveness equally requires the development 
Predrag Bejaković. Education, Employability and Labour Force Competitiveness in Croatia

PROBLEMS

OF EDUCATION

IN THE $21^{\text {st }}$ CENTURY

Volume 58, 2014

of trust, availability of information and effective government activity. A successful political and economic transition requires a sense of social solidarity (trust in other people is a key component of social solidarity), just and dependable institutions, observance of laws, and above all political institutions that provide what citizens want the most: prosperity. In all mentioned the impact of education can be of crucial importance.

\section{References}

Acemoglu, D., Pischke, J. S. (1999). Beyond Becker: Training in imperfect labor markets. Economic Journal, 109 (453), 112-142. doi: 10.1111/1468-0297.00405

Acemoglu, D., \& Robinson, J. (2012). Why Nations Fail: The Origins of Power, Prosperity, and Poverty. New York: Crown Business.

Aghion, P., \& Howitt, P. (1998). Endogenous Growth Theory. Cambridge: The MIT Press.

Atkinson, J. (1984). Manpower strategies for flexible organizations. Personnel Management, 16 (8), 28 31.

Barro, J. R., \& Sala-i-Martín, X. (1995). Economic Growth. New York: McGraw-Hill.

Barro J. R. (1998). Determinants of Economic Growth, A Cross-Country Empirical Study. Cambridge; London: The MIT Press.

Barro, R. J., \& Lee, J. W. (2001). Schooling Quality in a Cross-Section of Countries. Economica, 68, 465488. doi: 10.1111/1468-0335.00257

Bejaković, P. (2004). Labor Force Competitiveness in Croatia: status and problems. In P. Bejaković and J. Lowther (Ed.), Croatian human resource competitiveness study (pp. 1-15). Zagreb: Institute of Public Finance.

Bejaković, P. (2005). How prepared is Croatia for a knowledge-based society? In K. Ott (Ed.), Croatian Accession to the European Union: Facing the Challenges of Negotiations (pp. 107-126). Zagreb: Institute of Public Finance and Foundation Friedrich Ebert.

Bejaković, P., Bratić, V., Sopek, P., \& Štefica, V. (2009). The Analysis of the Educational Needs in Small and Medium Enterprises with Particular Stress on Entrepreneurial Skills. Zagreb: Croatian Chamber of Economy.

Benhabib, J., \& Spiegel, M. (1994). The Role of Human Capital in Economic Development: Evidence from Aggregate Cross-Country Data. Journal of Monetary Economics, 34 (2), 143-173. doi: 10.1016/0304-3932(94)90047-7

Berryman, S., \& Drabek, I. (2002). Mobilizing Croatia's Human Capital to Support Innovation-Driven Growth. Washington: World Bank.

Blomström, M., \& Meller, P. (Eds.) (1991). Diverging Paths. A Century of Latin American \& Scandinavian Economic Development. Baltimore: Johns Hopkins University Press.

Commission of the European Communities Brussels (2006.). Communication from the Commission to the Council and to the European Parliament: Efficiency and equity in European education and training systems. Brussels: Commission of the European Communities.

Cullis, J., \& Jones, P. (1998). Public Finance and Public Choice. New York; Oxford: Oxford University Press.

Boateng, S. K. (2009). Significant country differences in adult learning. Statistics in Focus, 44, 1-12.

Dearing Report (by Dearing, R.) (1997). National Committee of Inquiry into Higher Education. Retrieved from: http://www.lifelonglearning.co.uk

Griffith, R., (2000). How important is business $I \& R$ for economic growth and should the government subsidise it? London: Institute for Fiscal Studies.

Griliches, Z., \& Lichtenberg, F. (1984). Inter-industry technology flows and productivity growth: A reexamination. The Review of Economics and Statistics, 66 (2), 324-329. doi:10.2307/1925836

Griliches, Z. (Ed.) (1984). R\&D, Patents and Productivity. doi: 10.7208/ chicago/9780226308920.001.0001

Guisan, M. C., Aguayo, E., \& Exposito, P. (2001). Economic Growth and Cycles: Cross-Country Models of Education, Industry and Fertility and International Comparisons. Applied Econometrics and International Development, 1 (1). Retrieved from: http://www.usc.es/ economet/reviews/aeid111. pdf. 
Haddad,W. D., Carnoy, M., Rinaldi, R., \& Regel, O. (1990). Education and Development Evidence for New Priorities. World Bank Discussion Papers 95. Retrieved from: http://www-wds.worldbank. org/external/default/WDSContentServer/WDSP/IB/2000/01/11/000178830 98101903574266/ Rendered/PDF/multi_page.pdf

Hall, H. B. (1996). The Private and Social Returns to Research and Development: What Have We Learned? In: L. R. Bruce and C. E. Barfield (Ed.). Technology, R\&D, and the Economy. Washington, DC: The Brookings Institution and the American Enterprise Institute.

Hall, H. B. (2002). The Financing of Research and Development. NBER Working Paper Series, Working Paper 8773. Retrieved from: http://www.nber.org/papers/w8773

Hall, B. H., \& Mairesse, J. (1995). Exploring the Relationship between R\&D and Productivity in French Manufacturing Firms (PR). NBER Working Paper Series, Working Paper 3956.

ILO, (2002). Key Indicators of the Labour Market 2001-2002. Geneva: International Labour Office.

Jahoda, M. (1982). Employment and unemployment. Cambridge: Cambridge University Press.

Landes, D. (1999). The Wealth and Poverty of Nations. London: Abacus.

Lowther, J. (2004). The Quality of Croatia's Formal Education System. In P. Bejaković and J. Lowther (Ed.), Croatian human resource competitiveness study (pp. 1-15). Zagreb: Institute of Public Finance.

Meier, M. G., \& Rauch, E. J. (2000). Leading Issues In Economic Development. New York and Oxford: Oxford University Press.

Miyamoto, K. (2003). Human Capital Formation and Foreign Direct Investment in Developing Countries. OECD Technical Papers No. 211. Retrieved from: http://www.oecd.org/dataoecd/45/25/5888700. pdf

Moj posao, (2005). Istraživanje o edukativnim potrebama i ponudi na području Republike Hrvatske (A Survey on educational needs and offer in Zagreb area). Zagreb: Moj posao. Retrieved from: http:// www.mojposao.net/jseeker_wiki.php?sessionId=b1ac3d85b59751f5a4b5e325e3de6f6e\&wikiNa me=Edukacija

OECD, (1997). Thematic Review of the Transition from Initial Education to Working Life: Czech Republic. Paris: OECD.

OECD, Centre for Educational Research and Innovation, (2001). The Well-Being of Nations: The Role of Human and Social Capital Organisation. Retrieved from: www.oecd.org/site/worldforum/33703702. pdf

OECD, (2002). OECD Science, Technology and Industry Scoreboard 2001 - Towards a knowledgebased economy. Retrieved from: http://www1.oecd.org/publications/e-book/92-2001-04-1-2987/ A.3.htm.

OECD, (2003). Reviews of National Policies for Education: South Eastern Europe, Volume 1: Albania, Bosnia-Herzegovina, Bulgaria, Croatia, Kosovo. Paris: OECD.

OECD, (2005). Education at Glance, OECD Indicators 2005. Paris: OECD.

OECD, (2009). Education at Glance, OECD Indicators 2009. Retrieved from: http://www.oecd.org/education/skills-beyond-school/43636332.pdf

Pološki Vokić, N., Frajlić, D., (2004.), Croatian Labor Force Competitiveness Indicators: Results of Empirical Research. In P. Bejaković and J. Lowther (Ed.), Croatian human resource competitiveness study (pp. 59-74). Zagreb: Institute of Public Finance.

Porter, M. (1990). The Competitive Advantage of Nations. London: Macmillan.

Riddell, W. C. (2004). The Social Benefits of Education: New Evidence on an Old Question., Retrieved from: http://www.utoronto.ca/president/04conference/downloads/Riddell.pdf.

Sachs, J., Zinnes, C., \& Eilat, Y. (1999), Benchmarking competitiveness in transition economies, Harvard Institute for International Development. Washington, DC: United States Agency for International Development.

Skjolstrup, K. (2008). Human Resource Development Country Analysis for Croatia. ETF Working Paper, May 2008 Retrieved from: http://www.etf.europa.eu/web.nsf/pages/EmbedPub EN?OpenDocument\&emb=/pubmgmt.nsf/(WebPublicationsbyyearR)/89378B382E606E18C125 74BB00286656? OpenDocument

Sondergaard, L., Murthi, M., Abu-Ghaida, D., Bodewig, C., \& Rutkowski, J. (2012). Skills, Not Just Diplomas Managing Education for Results in Eastern Europe and Central Asia. Washington, DC: The International Bank for Reconstruction and Development and The World Bank.

Sopek, P. (2011). Efficiency of public expenditure on education in Croatia. Newsletter, 12 (61) 1-12. Retrieved from: http://www.ijf.hr/upload/files/file/ENG/newsletter/61.pdf 
Predrag Bejaković. Education, Employability and Labour Force Competitiveness in Croatia

PROBLEMS

OF EDUCATION

IN THE $21^{\text {st }}$ CENTURY

Volume 58,2014

26

Straubhaar, T. (2000). International Mobility of the Highly Skilled: Brain Gain, Brain Drain or Brain Exchange. Hamburg Institute of International Economics, Discussion Paper, 88. Retrieved from: http://www.hwwa.de/Publikationen/Discussion_Paper/2000/88.pdf

Trostel, P., Walker, I. \& Woolley, P. (2002). Estimates of the economic return to schooling for 28 countries. Labour Economics, 9 (1), 1-16. doi: 10.1016/S0927-5371(01)00052-5

World Bank (2002) Constructing Knowledge Societies: New Challenges for Tertiary Education. Washington, D.C: World Bank.

World Bank (2005). Enhancing job opportunities in Eastern Europe and the former Soviet Union. Retrieved from: http://europeandcis.undp.org/uploads/public1/files/vulnerability/Senior\%20Economist $\% 20 \mathrm{Web} \% 20$ site/Publications/Enhancing\%20job\%20opportunities\%20Eastern\%20Europe $\% 20$ and $\% 20$ the $\% 20$ Former $\% 20$ Soviet $\% 20$ Union.pdf

World Economic Forum (1997). The Global Competitive Report 1997. Geneva: World Economic Forum.

Advised by Laima Railienè, University of Šiauliai, Lithuania

Received: January 23, 2014

Accepted: February 15, 2014

Predrag Bejaković

Senior Researcher, Institute of Public Finance, Smiciklasova 21, 10000

Zagreb, Croatia.

E-mail: predrag@ijf.hr 